\title{
EFIKASI DIRI DAN DUKUNGAN SOSIAL KELUARGA MEMPREDIKSI MINAT BERWIRAUSAHA PADA MAHASISWA
}

\author{
Reti Nurhayati, Syarifah Farradinna*, dan Sigit Nugroho \\ Fakultas Psikologi Universitas Islam Riau \\ Jalan Kaharuddin Nasution Np. 113 Pekanbaru, 28284,Riau, Telp:+62-761-674.674 \\ *Email: syarifah.farradinna@psy.uir.ac.id
}

\begin{abstract}
Abstrak
Perkembangan ekonomi global menuntut individu untuk lebih kreatif dan inovatif dalam berwirausaha. Namun pada kenyatannya individu lebih banyak memilih mencari pekerjaan dibandingkan membuka usaha sendiri atau berwirausaha. Hal ini bisa dimulai dengan menumbuhkan minat berwirausaha pada mahasiswa. Penelitian ini bertujuan untuk mengetahui pengaruh efikasi diri dan dukungan sosial keluarga terhadap minat berwirausaha pada mahasiswa. Subjek dalam penelitian ini adalah mahasiswa Universitas Islam Riau sebanyak 394 mahasiswa dengan menggunakan teknik cluster random sampling. instrumen dalam penelitian ini menggunakan skala minat berwirausaha, skala efikasi diri dan skala dukungan sosial keluarga. Data dianalisis dengan menggunakan regresi linear berganda deangan menggunakan program SPSS versi 23 for windows. Berdasarkan uji analisis diperoleh $\mathrm{F}=8,121$ dan $\mathrm{p}=0,000(\mathrm{p}<0,05)$. Hasil penelitian menunjukan terdapat pengaruh yang positif dan signifikan signifikan antara efikasi diri dan dukungan sosial keluarga terhadap minat berwirausaha pada mahasiswa. Adapun kontribusi yang diberikan sebesar $R^{2}=0,052$ atau $5,2 \%$. Hal ini berarti menunjukkan pengaruh efikasi diri dan dukungan sosial keluarga terhadap minat berwirausaha sebesar 5,2\%. Universitas perlu melakukan pelatihan kewirausahaan untuk membangun niat kewirausahaan bagi siswa. Pada saat yang sama, konseling dan seminar untuk orang tua untuk memberikan dukungan sosial kepada siswa tentang pentingnya membangun niat kewirausahaan. Implikasi dari penelitian ini adalah untuk memberikan pengetahuan kepada orang tua tentang pentingnya dukungan sosial mereka dalam mendorong siswa untuk menjadi wirausaha.
\end{abstract}

Kata Kunci : efikasi diri, dukungan sosial, keluarga, minat berwirausaha

\section{SELF-EFFICACY AND FAMILY SOCIAL SUPPORT PREDICTS ENTERPRENEURSHOP INTEREST AMONG COLLEGE STUDENTS}

\begin{abstract}
The development of the global economy requires individuals to be more creative and innovative in entrepreneurship. But in reality, individuals prefer to find a job rather than open their own business or entrepreneurship. This can start with a growing interest in entrepreneurship to college students. This study aims to determine the effect of self-efficacy and family social support on entrepreneurship interest in college students. Research subjects were college students of the Islamic University of Riau as many as 394 college students methods using cluster random sampling techniques. instruments in this study using the scale of interest in entrepreneurship, self-efficacy scale and scale of family social support. The data analysis technique was using multiple regression by SPSS version 23 for windows. Based on analysis test obtained $F=8,121$ and $p=$ $0,000(p<0,05)$. The result showed that there is a positive significant positive effect between self-efficacy and family social support to entrepreneurship interest in college students. The contribution given is $R 2=0.052$ or $5.2 \%$. Universities need to conduct entrepreneurship training to build entrepreneurial intentions for students. At the same time, counseling and seminars for parents to provide social support to students about the importance of building entrepreneurial intentions. The implication of this study is to provide knowledge to parents about the importance of their social support in encouraging students to become entrepreneurs.
\end{abstract}

Keywords: self-Efficacy, family social, support, entrepreneurship interest 


\section{Pendahuluan}

Kementerian Koperasi dan UKM telah melakukan berbagai upaya untuk meningkatkan minat di kalangan mahasiswa dalam hal wirausaha. Salah satu usaha pemerintah dengan meluncurkan Gerakan Mahasiswa Pengusaha di beberapa universitas di Indonesia (Yasa, 2018). Gerakan ini sebagai upaya pemerintah guna mendukung perguruan tinggi untuk menumbuhkan minat kewirausahaan di kalangan mahasiswa. Pemerintah telah menyediakan berbagai fasilitas dan kemudahan kepada calon pelaku usaha muda seperti mahasiswa dalam upaya menumbuhkan minat berwirausaha seperti menyediakan pelatihan dan keterampilan manajerial kepada mahasiswa melalui Kementerian Ristek Dikti yang bekerjasama dengan Universitas (Lestari \& Wijaya, 2012). Kenyataannya, ketertarikan dan minat menjadi pelaku usaha dikalangan mahasiswa dan para alumni belum menunjukkan peningkatan dalam jumlah dan kualitas barang dan jasa nya. Padahal, kontribusi UMKM bagi penyerapan tenaga kerja domestik dan peningkatan ekonomi negara dapat mencapai hingga 90 persen. Peran pelaku usaha sangat penting dalam memberikan kontribusi bagi peningkatan pendapatan ekonomi non-pertanian, dan mengembangkan usaha kecil dan menengah dalam revolusi industri (Aghajani, Shababi, \& Fattahi, 2012).

Pertumbuhan ekonomi Indonesia dari hasil kepemilihan usaha hanya mampu mencapai kurang dari 2 persen dari penduduk Indonesia, berbanding dengan negara-negara ASEAN lainnya seperti Singapura, dan Malaysia (Barley, 2014). Beberapa ahli menyebutkan fenomena ini disebabkan karena masyarakat nya, khususnya di kalangan mahasiswa memandang tekanan besar sebagai pelaku usaha, menurut mereka faktor psikologis sebagai pangkal dari kecemasan dan ketakutan tersendiri bagi mahasiswa sebagai calon pelaku usaha. Beban dan tuntutan perubahan lingkungan secara drastis seperti pengelolaan debet dan kredit, perekrutan dan pelatihan karyawan, pemenuhan target dan deadline, pengurusan birokrasi dan keseimbangan kerja dan keluarga dimungkinkan dapat menyebabkan meningkatnya stres dan gangguan psikologis (Rytkonen \& Strandvik, 2005). Ketua Badan Perwakilan Daerah (BPD) Himpunan Pengusaha Muda wilayah Riau menjelaskan bahwa Provinsi Riau termasuk intensitas minat bagi Pemuda Riau lebih sedikit berbanding provinsi lainnya. Padahal, Pemerintah telah mengalokasikan dana sebesar 1,2 Triliun Rupiah untuk memberdayakan dan mengembangkan unit usaha dan pengusaha muda di seluruh kabupaten dan kota di Provinsi Riau (Indra, 2018).

Selain itu pula, banyak universitas menawarkan berbagai usaha dengan mengembangkan kurikulum yang berisikan pendidikan bisnis guna memacu minat berwirausaha di kalangan mahasiswa (Kabir, Haque \& Sarwar, 2017). Berbagai upaya dalam saling melibatkan pengetahuan dan kewirausahaan dalam dunia pendidikan seperti perguruan tinggi jelas menunjukkan bahwa Pendidikan Tinggi adalah tempat strategis untuk menumbuhkan dan mengembangkan minat kewirausahaan di kalangan mahasiswa (Nastiti, Indarti, \& Rostiani, 2010). Peran Pergguran Tinggi sangat berpengaruh kepada pembaharuan dengan menyertakan dan menerapkan kurikulum kewirausahaan untuk mendorong mahasiswa menjadi seorang pengusaha muda setelah mereka menjadi sarjana (Sahban, Ramalu \& Syahputra, 2016). Seperti yang telah diketahui dari studi terdahulu bahwa mereka yang memperoleh pengetahuan melalui pendidikan formal diketahui lebih kreatif untuk mengembangkan kemampuan dan melihat peluang lebih banyak dari lingkungan mereka (Patricia \& Silangen, 2016).

Beberapa fakta studi menunjukkan bahwa faktor berkembanganya kewirausahaan adalah adanya keinginan untuk membangun ekonomi yang lebih baik (Mohamad, Lim, Yusof \& Soon, 2015). 
Satu studi menjelaskan bahwa tingkat pendidikan menunjukkan pengaruh terhadap kecenderungan minat seseorang untuk memutuskan pemilihan karirnya (Hendarman, 2010). Peneliti menyimpulkan bahwa pembelajaran di perguruan tinggi lebih menekankan kepada menyiapkan sumber daya manusia sebagai pencari kerja, bukan sebagai menciptakan kerja. Selain itu pula, diprediksi bahwa faktor psikologis individu menjadi salah satu pondasi yang dapat membentuk kepribadian individu memiliki keyakinan dan motivasi untuk berminat menjadi wirausahawan. Beberapa ahli sependapat bahwa pendidikan dan pengajaran kewirausahaan tidak saja sebagai fitur penting, namun demikian, faktor psikologis seperti efikasi diri dalam menunjukkan individu lebih bertahan dengan minat mereka dalam bisnis yang inovatif (Lee, Chang, \& Lim, 2005). Minat berwirausaha dijelaskan berkaitan dengan dorongan dari dalam individu untuk memutuskan sebagai pelaku usaha, karena individu perlu memiliki keyakinan akan kemampuan dan keinginan untuk maju ( $W u$ \& $W u, 2012$ ). Efikasi diri kewirausahaan diketahui sebagai kemampuan individu dalam meyakini dirinya untuk mencapai keberhasilan dan mampu mengontrol dirinya terhadap hal-hal negatif yang mungkin terjadi (Drnovsek, Wincent \& Cardon, 2010).

Berdasarkan kepustakaan minat berwirausaha dirujuk dari karya Ajzen (1991) sebagai teori tindakan beralasan. la menekankan bahwa minat direspon dari perilaku yang direncanakan dan selanjutnya diproses oleh pikiran, yang mana dapat memprediksi dua dimensi iaitu sikap dan norma sosial. Oleh karena individu memiliki kecenderungan berperilaku yang bertujuan, Ajzen (1991) memodifikasi teori ini untuk menjelaskan kekuatan manusia dalam merencanakan dan mencoba kembali keinginan mereka untuk mencapai tujuan. Intensi merupakan anteseden bagi perilaku terencana yang dapat mempengaruhi individu dalam kecenderungan berperilaku, bagaimana terbentuknya bergantung kepadda kesesuaian antara keyakinan dan persepsi individu dalam memberikan respon (Kruger, 2000).

Teori kognitif sosial menggambarkan efikasi diri sebagai term yang digunakan untuk menilai individu atas kemampuan nya untuk melakukan beberapa tindakan (Bandura, 1999). Beberapa sumber yang menjadi faktor kuatnya efikasi diri individu terhadap kemampuan mereka adalah menguasai berbagai pengalaman pribadi agar tidak mudah putus asa dan tangguh (Bandura, 1999). Efikasi diri sesuai dalam menjelaskan intensi kewirausahaan pada mahasiswa, karena dapat mengukur penilaian keyakinan individu dari perspektif internal (Drnovsek et al, 2010). Bahkan peneliti lain memandang bahwa efikasi diri merupakan prediktor baik untuk menentukan awal intensi kewirausahaan, khususnya pada mahasiswa (Kruger, Reilly, \& Carsrud, 2000). Selain dorongan dari dalam diketahui bahwa faktor luar diri individu turut memberikan pengaruh kepada intensi kewirausahaan mahasiswa. Salah satu penelitian dari Indonesia misalnya menyebutkan bahwa dukungan sosial dapat memberikan impak kepada keinginan dan kemauan mahasiswa menjadi pengusaha (Pratiwi \& Wardana, 2016).

Dukungan sosial didefinisikan sebagai suatu proses transaksional berupa interaksi aktif antara individu dengan pemberi dukungan, seperti orang tua (House, 1981). Dukungan sosial orang tua berperan penting dalam mengembangkan minat mahasiswa dalam berwirausaha (Lee, WOng, Foo \& Leung, 2011). Beberapa aspek penting yang terkait dengan hal itu adalah ketersediaan sumber daya tambahan dari hubungan kekerabatan. Studi terdahulu menjelaskan bahwa ikatan orang tuaanak memainkan peran penting dalam memberikan dukungan dan motivasi agar menjadi lebih kompeten secara sosial, memiliki kepercayaan diri yang lebih baik, mengajarkan tanggung jawab dalam mewujudkan minat mereka terhadap bisnis (Sahban, Ramalu, \& Syahputra, 2016). 
Oleh karena itu, peneliti perlu menguji hubungan efikasi diri dan dukungan sosial keluarga dengan minat kewirausahaan dalam sampel di kalangan mahasiswa di Universitas Islam Riau (UIR). Dalam kenyataan nya, UIR telah berupaya untuk melakukan revisi kurikulum untuk sebagian besar program studi yang ada di UIR, seperti program studi Psikologi dan ekonomi Manajemen. Selain itu pula secara umum Unviersitas medorong dengan menyelenggarakan berbagai pelatihan, seminar kewirausahaan dan memberikan peluang wirausahawan bagi para mahasiswa. Penelitian ini sangat relevan dengan tujuan pendidikan dan dinamika sosial kewirausahaan saat ini, ketika mempelajari minat berwirausaha dikalangan mahasiswa karena adanya keputusan preferensi karir bahkan cenderung mengeksplorasi pilihan lainnya. Peneliti perlu memberikan wawasan dari dalam dan luar individu untuk meningkatkan sikap positif seperti minat mahasiswa sebagai wirausahawan. Dengan demikian peneliti perlu mengambil satu asumsi bahwa efikasi diri memberikan positif pada minat berwirausaha, begitu pula dukungan sosial keluarga menunjukkan pengaruh positif terhadap minat berwirausaha. Selanjutnya, peneliti perlu menguji efikasi diri dan dukungan sosial keluarga secara simultan mempengaruhi minat berwirausaha dikalangan mahasiswa.

\section{Metode}

Penelitian yang telah dijalankan ini adalah penelitian korelasi yang terdiri dari tiga gejala yang diamati yaitu efikasi diri, dukungan sosial keluarga dan minat berwirausaha di kalangan mahasiswa.

\section{Instrumen Penelitian}

Minat berwirausaha telah dikembangkan yang berasal dari teori perilaku terencana yang kemudian dimodifikasi oleh Ajzen (1991) sebagai teori perilaku beralasan. Menurutnya, teori ini biasa digunakan untuk menjelaskan tingkah laku individu dalam menilai kecenderungan, yang mana terbagi atas tiga aspek penentu yaitu sikap, norma sosial dan kontrol kognitif (Ajzen, 2005). Sikap mendeskripsikan tingkat kemampuan individu dalam melakukan evaluasi terhadap perilaku, yang mana berkait dengan dengan konsekuensi yang akan terjadi akibat dari perilaku tersebut. Norma sosial atau norma subjektif merupakan tekanan sosial yang dihadapi agar dapat menunjukkan perilaku yang diinginkan, fungsi aspek penentu ini adalah untuk menggambarkan keyakinan normatif yang diperoleh dari orang lain atau referensi dalam mempengaruhi pengambilan keputusan. Sementara itu, aspek penentu ketiga yaitu kontrol kognitif seperti persepsi mengacu kepada asumsi individu dalam mempersepsi pengalaman nya yang berfungsi sebagai antisipasi ketika menghadapi hambatan. Aspek ini menggambarkan individu yang memiliki keyakinan kontrol terhadap perilaku ketika dihadapkan pada pada masalah, semakin kuat kontrol yang diterima, maka akan semakin besar minat individu menjadi seorang pengusaha. Dalam penelitian ini minat berwirausaha diuji dengan 48 butir item yang diadaptasi dari Pintrick dan Schunk (1996).

Efikasi diri. Efikasi diri dijelaskan sebagai term yang didefinisikan dari teori kognitif sosial, sebagai bentuk penilaian individu atas kemampuan nya dalam melakukan sesuatu guna mencapai suatu hasil (Bandura, 1999). Efikasi diri digambarkan pula sebagai suatu hal yang dipercaya dapat dilakukan dengan keterampilan dalam keadaan tertentu (Maddux, 2009). Salah satu pakar Efikasi diri Bandura (2006) membagi aspek pengukur nya kedalam tiga hal, yaitu Tingkat (level) menggambarkan perbedaan tingkat potensi individu mengembangkan kemampuan nya dalam mencapai tujuan. Menurut nya, keyakinan diri atas kemampuan membedakan individu terkait dengan fungsinya, tingkat tugas, dan tuntutan situasional yang ada saat itu. Unsur aspek kedua ialah kekuatan 
(strength) yang menggambarkan kekuatan individu dalam menilai kemampuan nya dalam menyelesaikan tugas dan tanggung jawabnya. Individu memberikan target kekuatan nya sesuai dengan kapabilitas potensi yang dimilikinya. Aspek pengukur efikasi diri terakhir adalah Generalisasi (generality), yang bermakna bahwa aspek ini mengukur pola dan tingkat lingkungan dalam memandang diri nya. Individu menilai diri mereka memiliki kemampuan dalam melakukan berbagai hal, dapat mengatasi pelbagai jenis pekerjaan dalam berbagai situasi. Keseluruhan aspek pengukur efikasi diri terdiri dari 48 butir item.

Dukungan sosial keluarga. Dukungan sosial menggambarkan peranan atau pengaruh yang ditimbulkan karena adanya dorongan dari luar individu, yang diberikan oleh keluarga, teman, sanak saudara, maupun rekan kerja. Salah satu ahli menjabarkan Dukungan sosial orang tua (House, 1981) mengandung dukungan yang bersifat dukungan emosi seperti empati, kepedulian, cinta dan kepercayaan; aspek dukungan lainnya adalah instrumental yaitu bantuan aktual dalam waktu, finansial, ketersediaan fasilitas, dan energi; sementara itu aspek dukungan terakhir yaitu informasi yang diberikan berupa memberikan pandangan, umpan balik, melakukan penilaian, memberikan nasehat, dan saran. Pandangan House (1981) kemudian dijelaskan dalam Sarafino (2006) mengembangkan 11 butir item yang terdiri dari 8 butir favorable dan 3 butir unfavorable.

Keseluruhan skala direspon dalam skala 5-poin, masing-masing respon adalah (1) sangat tidak setuju sampai dengan (5) sangat setuju. Sementara itu, analisis statistik yang digunakan dalam penelitian ini adalah analisis regresi berganda, digunakan untuk menilai efek efikasi diri dan dukungan sosial keluarga terhadap minat berwirausaha pada mahasiswa. Bersama dengan itu, analisis ini dibantu denan menggunakan SPSS (versi 21.0) digunakan untuk melakukan entri keseluruhan data, validasi, dan analisis. Pertama, analisis yang dilakukan adalah menguji asumsi keseluruhan variabel yang diteliti. Kedua, menguji statistik regresi berganda sekaligus menguji estimasi kontribusi efikasi diri dan dukungan sosial terhadap minat berwirausaha di kalangan mahasiswa.

\section{Subjek penelitian}

Penelitian ini melibatkan mahasiswa fakultas psikologi Universitas Islam Riau sebanyak 394 orang yang dilakukan berdasarkan teknik sampel proportional random sampling, menurut Bungin (2016) cara ini dapat digunakan dengan cara mengundi sejumlah subjek penelitian yang memiliki sejumlah populasi setiap kelas yang memiliki kesempatan yang sama sebagai responden penelitian. Gambaran mahasiswa fakulatas Psikologi UIR yang telah memperoleh matakuliah kewirausahaan di semester ke-2, dilakukan secara bertahap dan sesuai dengan tahun angkatan. Para partisipan dibagi berdasarkan tahun akademik, mereka diminta untuk mengisi kuesioner yang telah disusun. Proses pengumpulan data ini berlangsung selama satu minggu, dapat diketahui bahwa sebanyak 190 orang (48.22 persen) mahasiswa pria dan 204 orang (51.78 persen) mahasiswa wanita telah berpartisipasi dalam penelitian ini. Pada umumnya usia mereka berkisar $18 \mathrm{sd} 23$ tahun, dan sebanyak 41.37 persen diantaranya telah berusia 22 tahun. Pada umumnya berada dalam semester 6 sebanyak 253 orang (64.21 persen), semester 2 sebanyak 89 orang (64.21 persen), semester 4 sebanyak 11 orang (22.58 persen) dan semester 8 sebanyak 41 orang (10.4 persen). 
Hasil

Berdasarkan analisis asumsi pada Tabel 1 yang dilakukan diketahui bahwa terdapat data berdistribusi tidak normal yaitu dukungan sosial keluarga, sementara dua variabel lainnya menunjukkan kebalikannya.

Tabel 1. Analisis Normalitas

\begin{tabular}{llll}
\hline \multicolumn{1}{c}{ Variabel } & \multicolumn{1}{c}{ Skor Ksz } & \multicolumn{1}{c}{$\boldsymbol{p}$} & \multicolumn{1}{c}{ Keterangan } \\
\hline Minat berwirausaha & .049 & .079 & Normal \\
Efikasi Diri & .049 & .079 & Normal \\
Dukungan sosial keluarga & .054 & .035 & Tidak Normal \\
\hline sumber: analisis data primer 2017 & &
\end{tabular}

Analisis ini digunakan untuk mengetahui sebaran sebuah data, pengujian nya dilakukan dengan uji kolmogorov smirnov $p>0.05$. Analisis selanjutnya adalah uji linearitas yang bertujuan untuk mengetahui apakah dua variabel mempunyai hubungan yang linear atau tidak secara signifikan. Berdasarkan analisis tersebut diketahui bahwa efikasi diri terhadap minat berwirausaha, dan dukungan sosial keluarga terhadap minat berwirausaha adalah memiliki hubungan linearitas. Hal ini dapat dilihat dalam Tabel 2.

Tabel 2. Analisis Linearitas antar variabel

\begin{tabular}{lll}
\hline \multicolumn{1}{c}{ Variabel } & \multicolumn{1}{c}{ Deviasi } & \multicolumn{1}{c}{$\boldsymbol{p}$} \\
\hline Minat berwirausaha - efikasi diri & .835 & .746 \\
Dukungan sosial keluarga - efikasi diri & 1.076 & .371 \\
\hline
\end{tabular}

Sumber: analisis data primer 2017

Berdasarkan hipotesis yang telah dijelaskan, analisis statistik regresi berganda dapat menjawab hipotesis tersebut. Dalam analisis ini diketahui bahwa efikasi diri dan dukungan sosial keluarga secara simultan menunjukkan pengaruh terhadap minat berwirausaha. Penjelasan ini dapat dilihat dalam Tabel 3.

Tabel 3. Uji Hipotesis

\begin{tabular}{cccccc}
\hline Model & B & B & t & F & Sig \\
\hline (Constant) & 47.785 & & & & \\
Efikasi Diri & .143 & .142 & 2.494 & & \\
Dukungan Sosial & .256 & .173 & 3.051 & & \\
Keluarga & & & & & \\
\hline
\end{tabular}

Sumber: analisis data primer 2015

Berdasarkan analisis regresi menunjukkan bahwa terdapat pengaruh positif yang signifikan efikasi diri dan dukungan sosial keluarga terhadap minat berwirausaha, hal ini menunjukkan bahwa hipotesis dalam penelitian ini diterima. Selain itu diketahui pula bahwa kontribusi efikasi diri dan dukungan sosial keluarga secara bersama-sama menunjukkan $\mathrm{R}^{2}$ sebesar 5.2 persen. Berdasarkan analisis deskriptif pula diketahui bahwa efikasi diri mahasiswa mayoritas merespon sedang sebanyak 37.37 persen selebih nya dalam kategori lainnya. Dukungan sosial keluarga yang diperoleh pula 
mayoritas merespon dukungan sosial keluarga dalam kategori Sedang sebanyak 37.37 persen.. Sejalan dengan respon pada minat berwirausaha mayoritas menunjukkan respon sedang dalam 37.37 persen. Hasil ini dapat dilihat dalam Tabel 4 dibawah ini.

Tabel 4. Deskripsi respon Efikasi Diri, Dukungan Sosial Keluarga dan Minat Berwirausaha

\begin{tabular}{ccccccc}
\hline & \multicolumn{2}{c}{ Efikasi Diri } & \multicolumn{2}{c}{$\begin{array}{c}\text { Dukungan Sosial } \\
\text { Keluarga }\end{array}$} & \multicolumn{2}{c}{ Minat Berwirausaha } \\
\cline { 2 - 7 } & Frek & $\%$ & Frek & $\%$ & Frek & $\%$ \\
\hline Sangat Tinggi & 25 & 8.41 & 29 & 9.76 & 27 & 9.09 \\
Tinggi & 75 & 25.25 & 91 & 30.63 & 77 & 25.92 \\
Sedang & 111 & 37.37 & 111 & 37.37 & 111 & 37.37 \\
Rendah & 73 & 24.57 & 52 & 17.05 & 70 & 23.57 \\
Sangat Rendah & 13 & 4.37 & 14 & 4.71 & 12 & 4.04 \\
\hline Total & $\mathbf{2 9 7}$ & & $\mathbf{2 9 7}$ & & $\mathbf{2 9 7}$ & \\
\hline
\end{tabular}

\section{Pembahasan}

Berdasarkan dari hasil deskriptif yang telah dilakukan dapat ditemukan bahwa dari 297 sampel yang diambil, maka terdapat rata-rata minat berwirausaha pada mahasiswa 190 atau 48.22 persen responden yang berada di kategori sedang, rata-rata efikasi diri 180 atau 20.3 persen responen yang berada dikategori tinggi, rata-rata dukungan sosial keluarga 160 atau 40,61 persen responden berada di kategori sedang.

Analisis pengujian hipotesis pada penelitian mengenai pengaruh efikasi diri dan dukungan sosial keluarga terhadap minat berwirausaha pada mahasiswa dengan menggunakan teknis analisis regresi linear berganda. Berdasarkan hasil uji regresi di temukan koefisien efikasi diri dengan minat berwirausaha dengan (R) 0.146 atau $(p>.05)$ sedangkan nilai kofisien dukungan sosial keluraga (R) .180 atau $(p>0,05)$ dengan demikian dapat disimpulkan bahwa terdapat pengaruh yang positif antara efikasi diri dan dukungan sosial keluarga terhadap minat berwirausaha pada mahasiswa.

Berdasarkan hasil analisis tersebut menunjukkan bahwa minat berwirausaha dapat diprediksi melalui adanya efikasi diri dan diterimanya dukungan sosial keluarga. Sistem dukungan sosial dari orang tua membuktikan bahwa penting dalam mengembangkan minat kewirausahaan mahasiswa, karena hubungan yang erat dalam ikatan keluarga memberikan dorongan dan motivasi tanpa pamrih (Sahban, Ramalu, \& Syahputra, 2016). Hasil analisis yang sama dalam penelitian ini diketahui bahwa dorongan dari dalam individu (efikasi diri) dan dari luar individu (dukungan sosial keluarga) menunjukkan nilai kesignifikan yang dapat mempengaruhi individu minat berwirausaha mahasiswa. Hal ini mungkin menjadi perhatian apabila dukungan sosial keluarga tidak hadir secara maksimal, dimana individu hanya memiliki kapasitasi dorongan dari dalam individu itu sendiri.

Bahasan lain menjelaskan dalam penelitian lalu bahwa minat berwirausaha pada diri seseorang, dalam penelitian yang dilakukan oleh Setiyawan (2017) yang dipengaruhi oleh lingkungan keluarga dan self efficacy memiliki pengaruh yang positif terhadap minat berwirausaha, semakin tinggi lingkungan keluarga dan efikasi diri maka semakin tinggi pula minat berwirausaha maka 
sebaliknya semakin rendah lingkungan keluarga dan efikasi diri maka semakin rendah pula minat berwirausaha siswa kelas XI program keahlian akuntansi di SMK Negeri 9 Semarang. Dorongan dari dalam diketahui bahwa terdapat pula faktor luar diri individu yang turut memberikan pengaruh kepada intensi kewirausahaan mahasiswa. Salah satu penelitian dari Indonesia misalnya menyebutkan bahwa dukungan sosial dapat memberikan impak kepada keinginan dan kemauan mahasiswa menjadi pengusaha (Pratiwi \& Wardana, 2016).

Minat berwirausaha didasari oleh pelbagai hal seperti keyakinan diri, tetapi perlu adanya dorongan dari luar seperti dukungan sosial terutama keluarga. Menurut satu penelitian sebelumnya menyatakan bahwa dukungan sosial yang paling diperlukan oleh seorang individu untuk menanamkan minat berwirausaha adalah dukungan informasi dan umpan balik (King, 2014). Terutama mahasiswa umpan balik seperti perasaan cinta, diperhatikan, dihargai, dihormati, dan dilibatkan dalam jaringan komunikasi dan kewajibannya secara timbal balik. Respon tinggi yang ditunjukkan pada dukungan sosial menunjukkan kehadiran keluarga sebagai hal yang penting dalam aktivitas individu yang masih berstatus mahasiswa, terutama pada saat mewujudkan minat mereka terhadap berwirausaha. Hal ini sejalan dengan penelitian sebelumnya bahwa kehadiran dukungan sosial keluarga adalah dorongan dari luar yang diperlukan bagi mahasiswa dalam mewujudkan niatnya (Koranti, 2013).

\section{Kesimpulan}

Terdapat hubungan yang positif dan signifikan antara efikasi diri dan dukungan sosial keluarga terhadap minat berwirausaha pada mahasiswa. Dengan demikian semakain tinggi efikasi diri dan dukungan sosial keluarga maka semakin tinggi pula minat berwirausaha pada mahasiswa, begitu jika sebaliknya, semakin rendah efikasi diri dan dukungan sosial keluarga maka semakin rendah pula minat berwirausaha pada mahasiswa. Implikasi dalam penelitian ini agar mahasiswa dapat mencari cara untuk meningkatkan efikasi diri melalui kehadiran dukungan sosial dari keluarga. Mungkin diperlukan pemberian pendidikan bagi orang tua akan pentingnya dukungan mereka terhadap minat sebagai wirausahawan semenjak dini. Walaupun adanya pendidikan kewirausahaan yang telah menjadi bagian dalam kurikulum universitas. Universitas dapat mengambil pandangan dari hasil penelitian ini, berdasarkan hasil penelitian perlu adanya dukungan universitas untuk memberikan pandangan kepada orang tua bahwa efikasi diri tidak cukup untuk membangun motivasi diri mahasiwa untuk memiliki niat kewirausahaan, tetapi harus adanya kehadiran dukungan sosial keluarga. Universitas dapat mengundang dan melakukan penyuluhan serta seminar bagi orang tua dan mahasiswa dengan tema-tema terkait kewirausahaann. Memandang penting dalam mewujudkan minat berwirausaha dengan meningkatkan efikasi diri dan menerima dukungan sosial keluarga. Peneliti menyarankan kepada peneliti setelah nya adalah meninjau kembali faktor-faktor lain yang dapat mendukung minat berwirausaha seperti motivasi berprestasi, kontrol lokus dan regulasi diri pada mahasiswa. 


\section{Daftar Pustaka}

Aghajani, H., Shababi, H., \& Fattahi, M. (2012). Role of Environmental factors on establishment of small and medium enterprises (SMEs): case of Mazadaran Province of Iran. World Applied Sciences Journal, 19 (1), 131-139

Ajzen, I. (1991). The theory of planned behavior. Organizational Behavior and Human Decision Processes, 50, 179-211

Ajzen, I. (2005). Attitude, personality and behavior (Second Edition). London: Open University Press

Bandura, A. (1999). A social cognitive theory of personality. In L. Pervin \& O. John (Ed.), Handbook of personality (2nd ed., pp. 154-196). New York: Guilford Publications. (Reprited in D. Cervone \& Y. Shoda [Eds.], The coherence of personality. New York: Guilford Press.)

Bandura, A. (2006). Guide for constructing self-efficacy scales. In F. Pajares \& T. Urdan (Eds.), Adolescence and education, Vol. 4: Self-efficacy beliefs of adolescents. Greenwich, CT: Information Age Publishing

Barley, T.N. (2014). Why Indonesia Lacks Entrepreneurs. http://www.thejakartapost.com/news/2014/12/20/why-indonesia-lacks entrepreneurs.html

Drnovsek, M., Wincent, J., \& Cardon, M. S. (2010). Entrepreneurial self-efficacy and business startup: developing a multi-dimensional definition. International Journal Entrepreneurial Behaviour \& Research, 16 (4), 329-348

Hendarman. (2010). Kebijakan dan Program Kewirausahaan di Perguruan Tinggi, Makalah dalam TOT Kewirausahaan bagi dosen, Direktorat Kelembagaan Ditjen Dikti.

House, J. S. (1981). Work stress and social support. Addison-Wesley Series on Occupational Stress. University of Michigan

Kabir, S.M., Haque, A., \& Sarwar, A. (2017). Factors affecting the intention to become an entrepreneur: A Study from Bangladeshi Business Graduates' Perspective. International Journal of Engineering and Information Systems, 1 (6), 10-19

King, L.A. (2014). Psikologi Umum. Jakarta: Salemba Humanika

Koranti, K. (2013). Analisis Pengaruh Faktor Eksternal dan Iternal Terhadap Minat Berwirausaha. Dalam Proceeding PESAT (Psikologi, Ekonomi,Sastra, Arsitektur \& Teknik Sipil, 5 (5)

Krueger, N.F. Jr, Reilly, M.D. \& Carsrud, A.L. (2000), "Competing models of entrepreneurial intentions", Journal of Business Venturing, Vol. 15 No. 5/6, pp. 411-32

Kruger, N.F. (2000). The cognitive infrastructure of opportunity emergence. Entrepreneurship Theory and Practice, 24 (3), 5-23 
Lee, L., Wong, P. K., Foo, M. Der, K. \& Leung, A. (2011). Entrepreneurial intentions: The influence of organizational and individual factors. Journal of Business Venturing, 26 (1), 124-136. doi:10.1016/j.jbusvent.2009.04.003

Lee, S.M., Chang, D. \&Lim, S.B. (2005). Impact of entrepreneurship education: a comparative study of the US and Korea. International Entrepreneurship and Management Journal, 1 (1), 27 43.

Lestari, R, B., \& Wijaya, T. (2012). Pengaruh pendidikan kewirausahaan terhadap minat berwirausaha. Jurnal ilmiah STIE MDP, 1 (2), 112-119

Maddux, J. E. (2009). Self-efficacy: The power of believing you can. In S. J. Lopez \& C. R. Snyder (Eds.), Oxford library of psychology. Oxford handbook of positive psychology (pp. 335-343). New York, NY, US: Oxford University Press

Mohamad, N., Lim, H.-K. Yusof, N. \& Soon, J.-J. (2015). Estimating the effect of entrepreneur education on graduates" intention to be entrepreneurs", Education+ Training, 57 (9), pp. 874-890

Nastiti, T., Indarti, N. \& Rostiani, R. (2010). Minat Berwirausaha Mahasiswa Indonesia dan Cina. Manajemen \& Bisnis, 9 (2), 188-189

Patricia., \& Silangen. (2016). The effect of entrepreneurship education on entrepreneurial intention in Indonesia. Development Research of Management (DeReMa) Jurnal Manajemen, 11 (1), 67-86

Pintrich, R. P. \& Schunk, D, H. (1996). Motivation In Education, Theory, Research, and Application. New Jersey: Prentice Hall

Pratiwi, Y., \& Wardana, M, I. (2016). Pengaruh Faktor Internal Dan Eksternal Terhadap Minat Berwirausaha Fakultas Ekonomi Dan Bisnis Universitas Udayana. E-Jurnal Manajemen Unud, 5 (8). 5215-5242

Rytkonen, M. H., \& Strandivik, T. (2005). Stress in business relationship. The Journal of Business Industrial Marketing, 20 (1), 12-22

Sahban, M. A., Ramalu, S. S., \& Syahputra, R. (2016). The influence of social support on entrepreneurial inclination among business students in Indonesia. Information Management and Business Review, 8 (3), 32-46

Sarafino, E. P. (2006). Health Psychology: biopsychologicall interactions. New York: John Wiley and Sons

Setiayawan, J. (2017). Pengaruh iself-efficacy, lingkungan keluarga dan lingkungan sekolah terhadap minat berwirausaha siswa SMK Muhammadiyah 1 Muntilan. Jurnal Pendidikan dan Ekonomi, 6 (3), 251-258

Wu, S., \& Wu, L. (2012), "The impact of higher education on entrepreneurial intentions of university students in China". Journal of Small Business and Enterprise Development, 15 (14), 752-774 
Efikasi Diri dan Dukungan Sosial Keluarga Memprediksi Minat Berwirausaha Pada Mahasiswa

Proyeksi, Vol. 14 (2)2019, 151-161

Yasa, A. (2018). Kemenkop dan UKM luncurkan Gerakan mahasiswa pengusaha. Bisnis.com, diakses pada https://ekonomi.bisnis.com/read/20180308/87/746945/kemenkop-dan ukmluncurkan-gerakan-mahasiswa-pengusahaan diakses pada tanggal 15 April 2019

Indra, Z. (2018). http://pekanbaru.tribunnews.com/2018/07/25/hipmi-riau-memiliki-1600pengusaha-pemula-binaan-di-12-kabupaten-kota diakses pada tanggal 15 April 2019 